\title{
固体高分子除湿セルの特性と空調への応用
}

\author{
学生員 客野 貴広* 学生員 服部紀公士* \\ 学生員 池田 孝伸* 正 員 荒木 拓人* \\ 正 員 恩田 和夫*
}

\section{Dehumidifying Characteristics of Polymer Electrolyte Dehumidifying Cell and its Application to Air Conditioner}

Takahiro Kyakuno*, Student Member, Kikuo Hattori*, Student Member, Takanobu Ikeda*, Student Member, Takuto Araki*, Member, Kazuo Onda*, Member

\begin{abstract}
Lots of the chlorofluorocarbon (CFC) has been released to atmosphere, resulting that the ozone layer in the stratosphere has been destroyed by the released CFC. Therefore, air conditioners without using CFC have been required to be developed. One of the candidates for such air conditioners is a combined conditioner of the dehumidifying cell by the proton exchange membrane (PEM) and the air cooler by water evaporation. But, we need to understand the operating principle of the dehumidifying cell because the performance of existing dehumidifying cells are not cleared. In this study, first we measured the transmissibility and the electro-osmotic coefficient $\mathrm{n}_{d}$ of water vapor through the membrane electrode assembly, the water vapor diffusivity through the diffusion electrode, and the mass transfer coefficient between the flow in channel and the diffusion electrode, as important factors to determine the dehumidifying performance. These factors were adopted in our analysis of the dehumidifying cell performance, where the conservation equations of mass and energy with an equivalent electric circuit of the cell are solved simultaneously. Calculated results can describe well the experimental dehumidifying performance. By using this simulation code we predicted the coefficient of performance (COP) of our novel air conditioner. Calculated COP's for test cell are as small as 0.10 or 0.21 , but could be 4 when we can get the PEM with high $n_{d}$ of 5 .
\end{abstract}

キーワード：除湿セル，空調装置，固体高分子膜，電気浸透係数，成績係数

Keywords: dehumidifying cell, air conditioner, proton exchange membrane, electro-osmotic coefficient, coefficient of performance

\section{1. まえがき}

現在普及しているフロンガスを冷媒とする空調装置は生 活の向上に大きく貢献してきた。しかし，使用量の増大に 伴うフロンの大気放出が成層圈のオゾン層を破壞してきた。 近年では環境問題への関心も高まり，オゾン層破懐を軽減 する代替フロンガスが普及している。しかし代替フロンで もオゾン層破壞が完全に防止される訳ではなく，フロンは 地球温暖化ガスにもなるので, フロンを使わない空調装置 の開発が注目されている。光の一つの候補として, 固体高 分子膜を使い, 室内の湿分を水蒸気電解セルで電気分解し, 更に電気浸透させながら室外入放出する除湿器 (1)(2) $の$ 応用 が考えられる。この除湿器は乾燥容器用として一部で市販

\footnotetext{
豊橋技術科学大学

T 441-8580 豊橋市天伯町雲雀ヶ丘 1-1

Toyohashi University of Technology

1-1, Hibarigaoka, Tempaku-cho, Toyohashi 441-8580
}

されている。我々は固体高分子膜 (PEM) による水蒸気の 電解と電気浸透を利用したこの除湿セルと水蒸発による吸 熱を併用した新しい空調法を提案した ${ }^{(3)(4)}$ 。しかし, 既存の 除湿セルは弚の動作が良く理解されていないため，光の動 作を実験的解析的に理解する必要がある。弚こで本研究で は, 除湿セルの特性を決める膜電極接合体 (MEA) の水蒸 気透過係数や電気浸透係数, 拡散電極の水蒸気拡散係数, 供 給流量の変化に伴う流路と拡散電極間の物質伝達率をまず 実測した。次にこれらの物性値などを使い，セル流路に沿 うガス流れ方向と膜に垂直な方向の二次元解析モデルを除 湿セルに対して構筑し, 物質とエネルギーの保存則と等価 電気回路を連立させ，除湿セルの実験結果を解析した。更 にこの解析コードを用いて, 除湿セルと水蒸発による吸熱 を併用した空調法の成績係数 (COP) を算出し, フロン冷 媒による市販空調機の性能と比較した。 


\section{2. 固体高分子除湿セルと空調への応用}

〈2 1〉 除湿セルの動作原理＼cjkstart除湿セルの概念図を図 1 に示す。水蒸気は次の電極反応で電気分解される。

$$
\begin{aligned}
& \text { アノード }: \mathrm{H}_{2} \mathrm{O} \rightarrow 2 \mathrm{H}^{+}+0.5 \mathrm{O}_{2}+2 \mathrm{e}^{-} . \\
& \text {カソード }: 2 \mathrm{H}^{+}+2 \mathrm{e}^{-} \rightarrow \mathrm{H}_{2} \ldots \ldots \ldots \ldots
\end{aligned}
$$

湿り空気中の水蒸気 $1 \mathrm{~mol}$ は $2 \mathrm{~mol}$ のプロトン $\left(\mathrm{H}^{+}\right)$と $0.5 \mathrm{~mol}$ の $\mathrm{O}_{2}$ に分解され， $\mathrm{H}^{+}$は MEA を通り，カソード へ移動する。カソードに $\mathrm{N}_{2}$ を供給した場合 (水蒸気電解 方式)， $\mathrm{H}^{+}$(は電子を受(取って $\mathrm{H}_{2}$ となる。 $\mathrm{H}^{+}$が MEA を 移動する際に，固体高分子膜 $(\mathrm{PEM})$ では $1 \mathrm{~mol} の \mathrm{H}^{+}$に $n_{d}[\mathrm{~mol}]$ (電気浸透係数) の水が付随する (電気浸透現象)。

電気浸透 : $2 \mathrm{H}^{+}+2 n_{d} \mathrm{H}_{2} \mathrm{O} \rightarrow 2 \mathrm{H}^{+} \cdot n_{d} \mathrm{H}_{2} \mathrm{O} \cdots \cdots$ (3)

つまり，アノードでは $2 n_{d}+1[\mathrm{~mol}]$ の水が除湿されること になる。しかしカソードの水蒸気濃度がアノードより高く なると，濃度勾配によりカソードからアノードへ水蒸気は 逆拡散する。このため除湿性能は逆拡散水と電気浸透水の バランスで決まる。

一方，カソードに空気を供給した場合（水蒸気ポンプ方 式)，カソードへ移動した $\mathrm{H}^{+}$は $\mathrm{O}_{2}$ と反応して $\mathrm{H}_{2} \mathrm{O}$ に戻 るため, $\mathrm{H}_{2} \mathrm{O}$ がアノードからカソードへ移動したように見 える。

$$
\text { カソード : } 2 \mathrm{H}^{+}+0.5 \mathrm{O}_{2}+2 \mathrm{e}^{-} \rightarrow \mathrm{H}_{2} \mathrm{O}
$$

水蒸気ポンプ方式では $\mathrm{H}_{2}$ が発生しないため, 電解動力は 濃淡電池の Nernst 起電力と過電圧で決められる。

〈2. 2〉電気浸透と水蒸発吸熱を併用する空調法(3)(4) 本 研究では試験した除湿セルの性能を元に，水の蒸発吸熱で 部屋の空気を冷却する冷風扇などで発生する水蒸気を本除 湿器で除く本提案の空調法の成績係数 (COP) も試算した。 水蒸気の移動を水蒸気電解と電気浸透のみとし, 逆拡散や 過電圧損失が無ければ，水蒸気電解方式による水蒸発電気 浸透による本空調法は (5) 式で表される理想的な COP を持

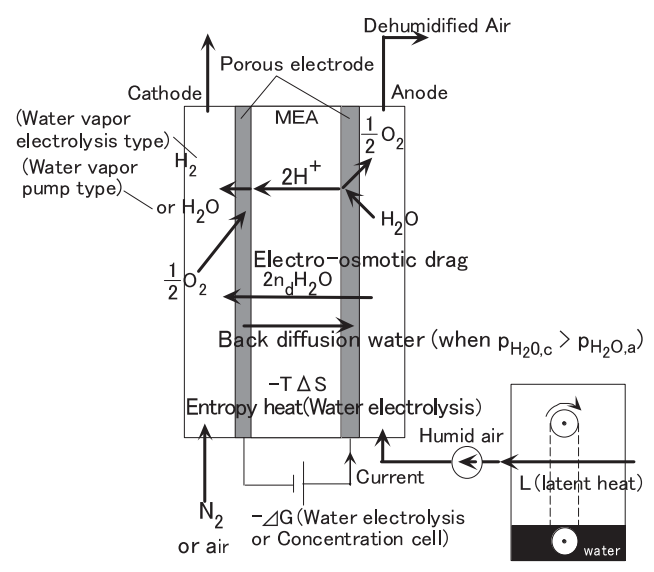

図 1 除湿セルの概念図

Fig. 1. Schematic diagram of dehumidifying cell. $\supset^{(3)(4)}$ 。

$$
C O P=\frac{T \Delta S+\left(2 n_{d}+1\right) L}{\Delta G}
$$

ここで, $T$ は温度 $[\mathrm{K}], L$ は水の蒸発潜熱 $[\mathrm{J} / \mathrm{mol}], \Delta G, \Delta S$ は乥れ先れ水蒸気電解のギブズエネルギー変化 $[\mathrm{J} / \mathrm{mol}]$, 工 ントロピー変化 $[\mathrm{J} / \mathrm{mol} / \mathrm{K}]$ である。ただし，ここでは簡単の ため記号は総て正の値とする。このときの $n_{d}$ と COP の関 係を图 2 に示す。市販されているフロン空調機の COP は 付帯設備や諸損失を含めて 4 6 程度である。本空調法が市 販のフロン空調機と同等の性能を持つには, 理想的な本方 法でも約 10 の $n_{d}$ が必要となる。なお，現在の固体高分子 形燃料電池 (PEFC) の $n_{d}$ は約 $1.6^{(5)}$, 水電解セル (PEEC) の $n_{d}$ は約 $4.8^{(6)}$ である。カソード側に空気を供給する水蒸 気ポンプ方式では $\langle 2 \cdot 1\rangle$ 節でも述べたように理想的には $\mathrm{H}_{2}$ が発生しないので, $T \Delta S$ と $\Delta G$ が消え, 除湿セルは濃淡電 池の Nernst 起電力と過電圧のみの動力となるので, $n_{d}$ が 大きければ高いCOP が期待できる。

\section{3. 膜物性測定と物質伝達率の整理}

〈3.1〉膜物性や物質伝達率などの測定法除湿セルの 性能を決める膜物性などを以下のように測定した。出入り 口で平均した水蒸気濃度を用い，セル全体の定常状態にお ける水蒸気移動は，流路ガスと拡散電極 (DIF) の間での

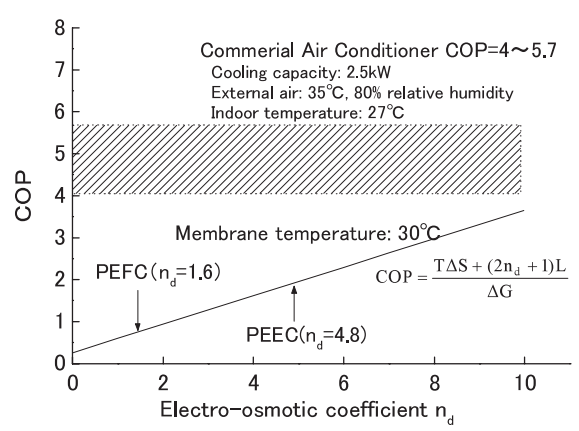

图 2 電気浸透係数 $n_{d}$ による水蒸発電気 浸透空調法の COP 変化

Fig. 2. Change of COP for water-evaporation/ electro-osmosis air conditioner by electro-osmotic coefficient $n_{d}$.

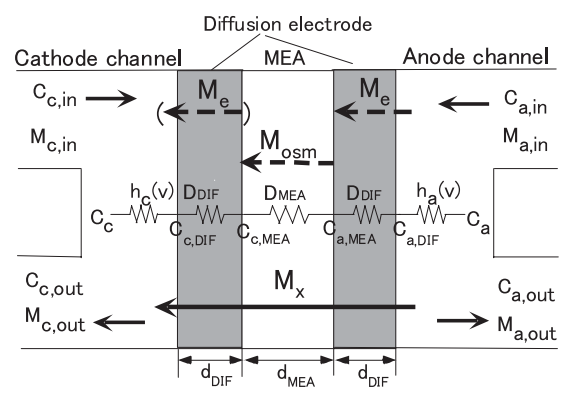

図 3 除湿セル中の水蒸気移動モデル

Fig. 3. Transport model of water vapor in dehumidifying cell. 


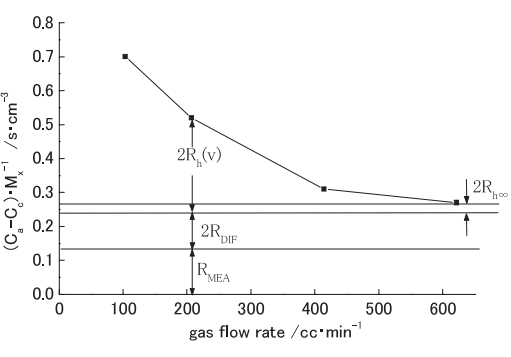

図 4 各種物質伝達抵抗の供給流量に対する変化

Fig. 4. Change of various mass-transfer resistances by gas flow rate.

物質伝達率 $h(v)$ を考慮すれば , 図 3 のように表せ , 以下の 式で記述できる。

$$
\begin{aligned}
& M_{x}=h_{a}(v)\left(C_{a}-C_{a, D I F}\right) A \\
& M_{x}=D_{D I F}\left(C_{a, D I F}-C_{a, M E A}\right) A / d_{D I F} \\
& M_{x}=D_{M E A}\left(C_{a, M E A}-C_{c, M E A}\right) A / d_{M E A} \\
& M_{x}=D_{D I F}\left(C_{c, M E A}-C_{c, D I F}\right) A / d_{D I F} \\
& M_{x}=h_{c}(v)\left(C_{c, D I F}-C_{c}\right) A \\
& \frac{C_{a}-C_{c}}{M_{x}}=\frac{1}{h_{a}(v) A}+\frac{1}{h_{c}(v) A}+2 \frac{d_{D I F}}{D_{D I F} A}+\frac{d_{M E A}}{D_{M E A} A} \\
& =2 R_{h}(v)+2 R_{D I F}+R_{M E A}
\end{aligned}
$$

ここで, $d_{i}, D_{i}$ は各層の膜厚 $[\mathrm{cm}]$,透過 (拡散) 係数 $\left[\mathrm{cm}^{2} / \mathrm{s}\right]$ であり， $C_{i}$ は構成要素間の水蒸気濃度 $\left[\mathrm{g} / \mathrm{cm}^{3}\right], M_{x}$ は図 3 に実線で示すアノードからカソードへ移動する水蒸気流量 [g/s] を表す。添え字は，DIF が拡散電極， $a$ がアノード， $c$ がカソードを表わす。なお, 本研究では水蒸気の移動を 検討しているので, 膜中は水蒸気が等価的に移動するとし てモデルを構筑している。また,$h_{i}(v)$ の $v$ は水蒸気を含む 供給ガス速度 $[\mathrm{cm} / \mathrm{s}]$ であり，供給ガス流量 $\mathrm{Q}\left[\mathrm{cm}^{3} / \mathrm{min}\right]$ を ガス流路の総断面積 $\left(6 \times 10^{-2} \mathrm{~cm}^{2} \times 8\right.$ 本) で割つて得ら れる。定常状態では各要素における $M_{x}$ は一定で, 各要素 で(6)〜(10) 式まで5 個の関係式が成立し，これらを整理す ると (11) 式が導出できる。ただし, $R_{h}(v)$ は $h_{a}(v)$ と $h_{c}(v)$ に対する平均物質伝達抵抗とする。(11) 式より移動抵抗は 图 4 のように物質伝達抵抗 $R_{h}(v), \mathrm{MEA}$ の透過抵抗 $R_{M E A}$, 拡散電極の拡散抵抗 $R_{D I F}$, の 3 つに分離できる。图 4 で $R_{M E A}$ や $R_{D I F}$ は水蒸気に対する MEA や拡散電極の物性値 で, 供給ガス流量に対して変わらないと思われるが， $R_{h}$ が 供給ガス流量により変わるのは, 膜圧方向に水蒸気が移動 するため, $h_{i}(v)$ か噴き出しや吸込みで変わるためと思われ

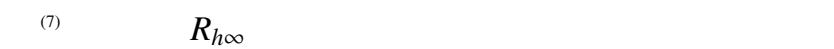
が無い時の物質伝達抵抗 $R_{h}(v)$ で近似し，A はセル電極面 積 $\left[\mathrm{cm}^{2}\right]$ を表す。

測定構成を図 5 に示す。アノードには空気を，カソード には窒素または空気をマスフロコントローラ (MFC) で流 量を調整し，加湿器を通して供給する。また，セルのセパ レータには恒温水を循環させ , セル温度を一定にして測定

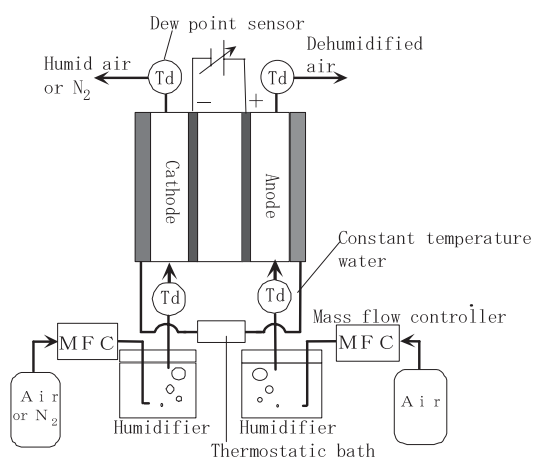

図 5 測定装置の構成

Fig. 5. Schematic diagram of measurement equipment.

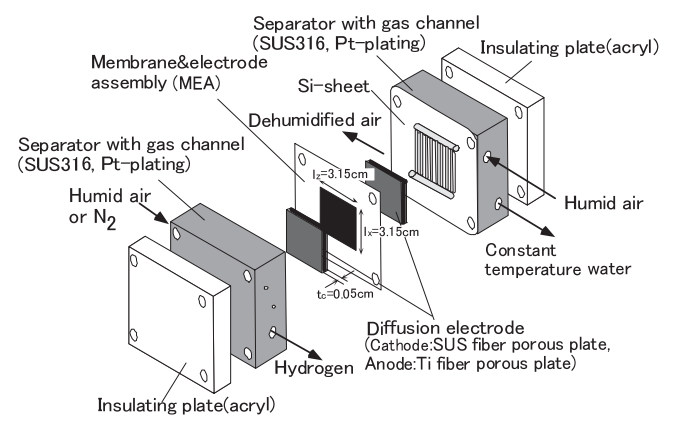

図 6 除湿セルの構成

Fig. 6. Schematic diagram of dehumidifying cell.

表 1 除湿セルの仕樣

Table 1. Specification of dehumidifying cell.

\begin{tabular}{c|c|c}
\hline \multicolumn{2}{c|}{ item } & material, thickness, size \\
\hline \multirow{2}{*}{ MEA } & PEM & Nafion117(thickness : $178 \mu \mathrm{m})$ \\
\cline { 2 - 3 } & Catalyst & Anode :Pt - Ir, Cathode :Pt \\
\hline \multicolumn{2}{c}{ Electrode area } & $10 \mathrm{~cm}^{2}$ \\
\hline \multirow{2}{*}{$\begin{array}{c}\text { Diffusion } \\
\text { electrode }\end{array}$} & Anode & Ti fiber porous plate(thickness: $500 \mu \mathrm{m})$ \\
\cline { 2 - 3 } & Cathode & SUS fiber porous plate (thickness: $500 \mu \mathrm{m})$ \\
\hline \multirow{2}{*}{$\begin{array}{c}\text { Gas Flow } \\
\text { channel }\end{array}$} & Anode & 8Parallel Paths(width:2mm,depth:0.3mm) \\
\cline { 2 - 3 } & Cathode & 8Parallel Paths(width:2mm,depth:0.3mm) \\
\hline
\end{tabular}

する。除湿セルの構成図を図 6 に, 光の仕樣を表 1 に示す。 PEM のアノード側に Pt-Ir , カソード側にPt の触媒を担持 した MEA を拡散電極て挟み，更に，流路付きセパレータ と絶縁板で挟んだ。

測定はセル温度を $30 \sim 50^{\circ} \mathrm{C}$ に変え，アノード加湿温度 をカソードより $10 \sim 16^{\circ} \mathrm{C}$ 高く保ち，供給ガス流量を $100 〜$ $600 \mathrm{cc} / \mathrm{min}$ に変えて行った。セルの出入口の露点は露点計 (図 5 の Td) で測定された。流路中の水蒸気濃度 $C_{a}, C_{c}$ は出入口の平均として (12) 式で, アノードからカソードへ 移動する水蒸気流量 $M_{x}$ は $M_{i}$ を水蒸気流出入量とし, (13) 式で算出した。両極での $M_{x}$ を平均し，(11) 式により全体 の移動抵抗を算出した。

$$
\begin{aligned}
& C_{j}=\left(C_{j, \text { in }}+C_{j, \text { out }}\right) / 2 \quad(j=a, c) \cdots \\
& M_{x}=M_{a, \text { in }}-M_{a, \text { out }}=M_{c, \text { out }}-M_{c, \text { in }}
\end{aligned}
$$




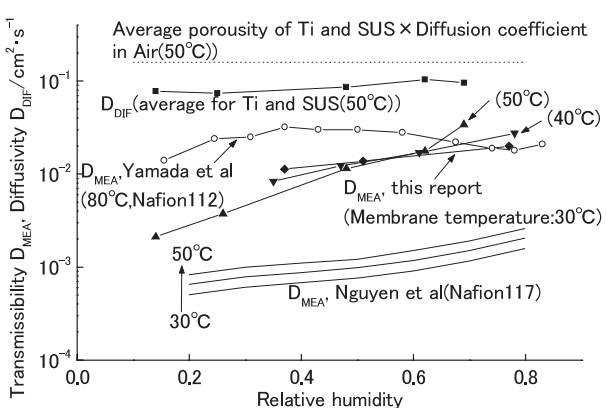

図 7 膜の透過係数 $D_{M E A}$ と電極の拡散係数 $D_{D I F}$ Fig. 7. Membrane transmissibility $D_{M E A}$ and porous electrode diffusivity $D_{D I F}$.

測定はMEA+拡散電極, MEA のみ, 拡散電極のみの 3 通 りに対して行い，乥れ光れの測定条件に対する $R_{h}(v) ， R_{D I F}$ ， $R_{M E A}$ の 3 つの值を求めた。

〈3. 2〉 水蒸気の膜の透過係数と拡散電極の拡散係数 図 4 のようにガス流量変化による変化分を除いて, (MEA+ 拡散電極) - (MEA のみ) と (拡散電極のみ) の平均から 拡散電極の水蒸気拡散係数を, (MEA+ 拡散電極) - (拡散 電極のみ) と (MEA のみ) の平均から MEA の水蒸気透過 係数を求めた。両電極を流れる流体の相対湿度の平均に対 する MEA の透過係数 $D_{M E A}$ と拡散電極の拡散係数 $D_{D I F}$ の測定結果を図 7 に示す。MEA の透過係数 $D_{M E A}$ は膜温

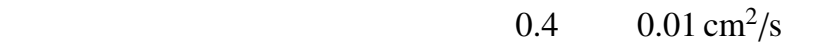

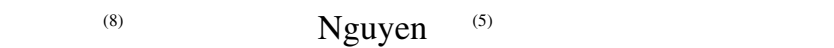
拡散電極の $D_{D I F}$ は相対湿度に寄らず約 $0.1 \mathrm{~cm}^{2} / \mathrm{s}$ で, Ti と SUS の平均多孔度と空気中水蒸気の拡散係数の積にほぼ一 致する。乥こで拡散電極の拡散係数 $D_{D I F, T i}, D_{D I F, S U S}$ は次 式で近似した。

$$
D_{D I F, k}=\varepsilon_{k} D_{\mathrm{H}_{2} \mathrm{O}-\text { air }}
$$

ただし， $D_{\mathrm{H}_{2} \mathrm{O}-\text { air }}$ は空気中水蒸気の拡散係数 $\left[\mathrm{cm}^{2} / \mathrm{s}\right], \varepsilon_{k}$ は $k$ 拡散電極の多孔度で, 後の解析では実験に即して以下の $\varepsilon_{k}$ を用いた。

Ti 拡散電極 : $\varepsilon_{T i}=0.3290$

SUS 拡散電極 : $\varepsilon_{S U S}=0.4213$

また，MEA の透過係数 $D_{M E A}$ は測定結果を近似した次式 で表した。

$$
D_{M E A}=0.0345 a_{M E A}-0.0035
$$

ただし， $a_{M E A}$ は両極での供給ガス相対湿度の平均である。

〈3.3〉物質伝達率の整理 图 4 に示した供給ガス流 量によって変わる物質伝達率 $h(v)$ を, 噴き出しや吸込みの ある平板に沿う流れ( を参考に，图8のように整理し，以 下の式で近似した。

$$
h(v) / h(v)^{0}=h_{1} \exp \left(h_{2} x\right) \cdot
$$

ここで, $h_{1}, h_{2}$ は以下のように温度の関数とし,$x$ は速度 の比を表す。

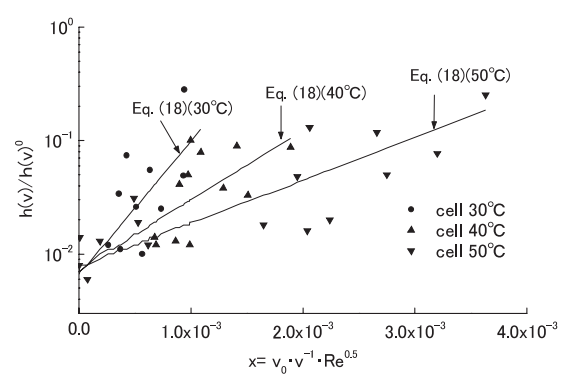

図 8 物質伝達率の整理

Fig. 8. Arrangement of mass-transfer coefficient.

$$
\begin{aligned}
& h_{1}=0.0023+2 \times 10^{-4} t_{\text {cell }}-1 \times 10^{-6} t_{\text {cell }}^{2} \ldots \ldots \\
& h_{2}=27153-1604 t_{\text {cell }}+33.2 t_{\text {cell }}^{2}-0.23 t_{\text {cell }}^{3} \ldots \\
& x=v_{0} v^{-1} R e^{0.5} \ldots \ldots \ldots \ldots \ldots \ldots \ldots \ldots \ldots \ldots
\end{aligned}
$$

ここで, $t_{\text {cell }}$ はセル温度 $\left[{ }^{\circ} \mathrm{C}\right], v_{0}$ は膜厚方向の水蒸気速度 $[\mathrm{cm} / \mathrm{s}], v$ は流路に沿うガス速度 $[\mathrm{cm} / \mathrm{s}], \operatorname{Re}$ は流路溝中ガ スの Reynolds 数, $h(v)^{0}$ は噴き出しや吸込みの無い管内流 に対する物質伝達率 $[\mathrm{cm} / \mathrm{s}]$ を表す。 $h(v) / h(v)^{0}$ は膜温度が 上昇すると減少し， $\left(v_{0} / v\right) \mathrm{Re}^{0.5}$ と共に大きくなる。ここで は噴き出しや吸い込みを伴う両極での $h(v)$ を個別に求める ことは難しいので, 両極の平均值で整理した。

〈3. 4〉電気浸透係数除湿セルに通電すると図 3 の破 線で示すように, 水蒸気電解量 $M_{e}$ とアノードからカソー ドへ電気浸透する水蒸気量 $M_{o s m}$ を〈3・1 節で述べた拡散 水蒸気に加える必要がある。つまり，通電時にアノードか らカソードへ動く水蒸気移動量 $M_{x}^{\prime}$ は (22) 式で表せる。

$$
M_{x}^{\prime}=M_{a, \text { in }}-M_{a, \text { out }}-M_{e}=M_{c, \text { out }}-M_{c, \text { in }} \cdots \cdots
$$

$M_{x}^{\prime}$ が一定の定常状態では通電時の各要素間で以下の関係 式が成立つ。

$$
\begin{array}{r}
M_{x}^{\prime}=h_{a}(v)\left(C_{a}-C_{a, D I F}\right) A-M_{e} \ldots \ldots \ldots \ldots \\
M_{x}^{\prime}=D_{D I F}\left(C_{a, D I F}-C_{a, M E A}\right) A / d_{D I F}-M_{e} \ldots \\
M_{x}^{\prime}=D_{M E A}\left(C_{a, M E A}-C_{c, M E A}\right) A / d_{M E A}+M_{o s m} \\
\ldots \ldots \ldots \ldots \ldots \\
M_{x}^{\prime}=D_{D I F}\left(C_{c, M E A}-C_{c, D I F}\right) A / d_{D I F} \ldots \ldots \ldots \\
M_{x}^{\prime}=h_{c}(v)\left(C_{c, D I F}-C_{c}\right) A \ldots \ldots \ldots \ldots \ldots
\end{array}
$$

$5 つ$ 関係式を $\langle 3 \cdot 1\rangle$ 節と同樣に整理すると， $R_{D I F}, R_{M E A}$ ， $R_{h}(v)$ には前節で整理した值を， $C_{a}$ と $C_{c}, M_{x}^{\prime}$ は測定から， また $M_{e}$ は通電量より求まるため $M_{o s m}$ が得られ， $n_{d}$ は (28) 式で求められる。

$$
n_{d}=\frac{M_{\text {osm }}}{18} \frac{F}{I}
$$

ここで,$F$ はファラデー定数 $(=96485 \mathrm{C} / \mathrm{mol}), I$ はセル 電流 [A] である。一方, カソードに空気を流す水蒸気ポン プ方式では, (17)，(18) 式の右辺に生成水量 $M_{e}$ の項を追 加し, 同樣に求めることが出来る。 $n_{d}$ は透過と電気浸透の 


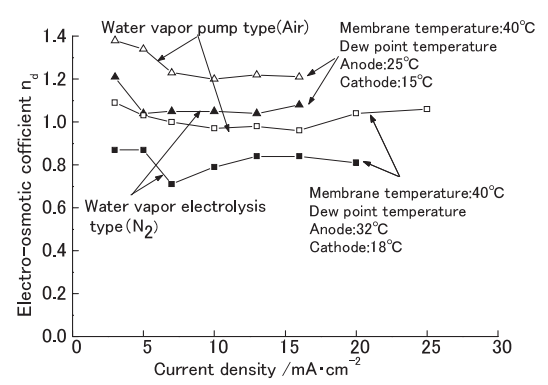

図 9 電気浸透係数の電流密度変化

Fig. 9. Change of electro-osmotic coefficient by current density.

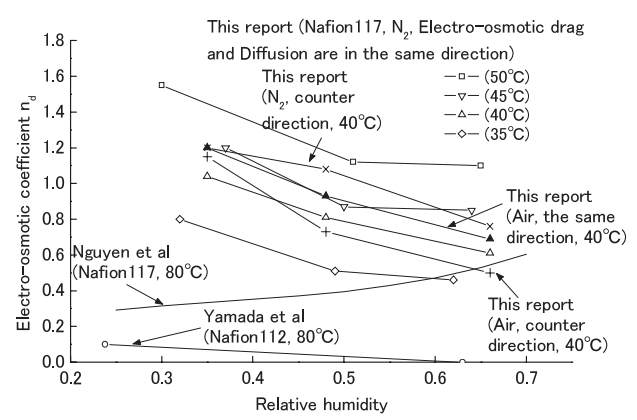

図 10 電気浸透係数の温度と相対湿度に対する変化 Fig. 10. Change of electro-osmotic coefficient by temperature and relative humidity.

向きが同方向と逆方向の両方で測定した。またカソード側 供給ガスは空気および室素とし，物質伝達率が充分高くな る供給流量で測定した。

電流密度に対する $n_{d}$ の測定結果を图 9 に示す。電流密 度に依存する $n_{d}$ は安田 ${ }^{(9)}$ も報告しているが, 我々の除湿セ ルは $10 \mathrm{~mA} / \mathrm{cm}^{2}$ 以上で運転するので，一定とみなし，相対 湿度と温度に対する变化を図 10 に示す。 $n_{d}$ は相対湿度の 上昇と共に減少している。供給ガスを窒素としたり，透過 と電気浸透が逆方向でもほぼ同じ測定結果が得られた。他 の報告值と比較すると，山田ら ${ }^{(8)} や$ Nguyen ら ${ }^{(5)}$ より大き い。我々が測定した $n_{d}$ は両方式の平均值として, 次式で整 理した。

$$
n_{d}=n_{1}+n_{2} a_{M E A}+n_{3} a_{M E A}^{2}
$$

ここで, $n_{1} \sim n_{3}$ は次式のように温度の関数とした。

$$
\begin{aligned}
& n_{1}=0.9806+0.0365 t_{M E A} \\
& n_{2}=-8.2456+0.063 t_{M E A} \\
& n_{3}=7.9265-0.0823 t_{M E A}
\end{aligned}
$$

ただし， $t_{M E A}$ は膜温度 $\left[{ }^{\circ} \mathrm{C}\right]$ を表す。

\section{4. 除湿セルの実験と解析, 空調への応用}

〈4 1〉除湿セルの実験 図 5 , 図 6 に示した実験構成 で, 水蒸気電解方式と水蒸気ポンプ方式に対して得られた $\mathrm{i}-\mathrm{V}$ 特性を比較して図 11 に示す。水蒸気電解方式では電解

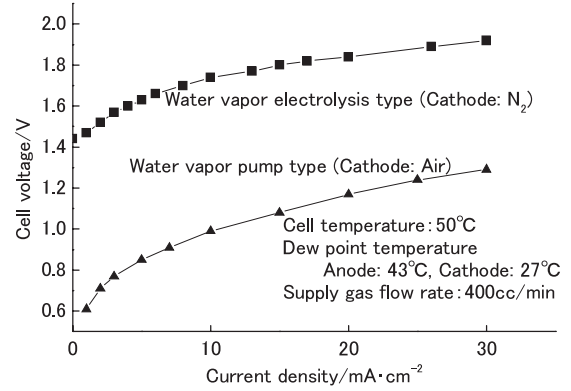

図 11 除湿セルの $\mathrm{i}-\mathrm{V}$ 特性

Fig. 11. i-V characteristics for dehumidifying cell.

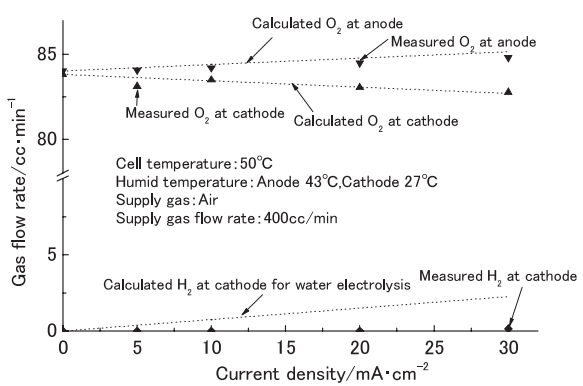

図 12 電流密度によるカソードとアノードでのガス

Fig. 12. Change of gas flow rate at cathode and anode by current density (water vapor pump type).

開始電圧が $1.4 \mathrm{~V}$ 近いのに対し，水蒸気ポンプ方式では水 蒸気電解電圧 $1.18 \mathrm{~V}$ より低い $0.6 \mathrm{~V}$ 付近から電流が流れて いる。水蒸気ポンプ方式の反応を更に確認するため, ガス クロによりカソードでの水素の生成量と，両極での酸素の 増減量を測定した。光れぞれの流量は両極て变化しない $\mathrm{N}_{2}$ を基準に, ガスクロで測定した濃度から計算した。測定結 果を図 12 に示す。カソードで $\mathrm{H}_{2}$ はほとんど発生せず，水 蒸気電解によるアノードでの $\mathrm{O}_{2}$ の増分や, 電解 $\mathrm{H}_{2}$ と反応 したカソードでの $\mathrm{O}_{2}$ の減少は通電量に近いため，(4) 式に 示したように $\mathrm{H}^{+}$はカソードにおいて $\mathrm{O}_{2}$ と反応して $\mathrm{H}_{2} \mathrm{O}$ になったことが分かる。

大きく低下するセル電圧は両極での $\mathrm{H}_{2} \mathrm{O}$ と $\mathrm{O}_{2}$ 分圧によ り決まる Nernst 起電力 $E_{\text {Nernst }}(33)$ 式に過電圧を加えた電 圧で記述できると思われる。

$$
E_{\text {Nernst }}=\frac{R T}{2 F} \ln \frac{p_{\mathrm{H}_{2} \mathrm{O}, a} p_{\mathrm{O}_{2}, c}^{0.5}}{p_{\mathrm{H}_{2} \mathrm{O}, c} p_{\mathrm{O}_{2}, a}^{0.5}}
$$

MEA が水電解用であるため, 燃料電池のカソード反応 (4) 式か効率よく進まず，電流密度が高くなると反応が不充分 で, 微量の $\mathrm{H}_{2}$ が発生することも分かった。なお, カソード に $\mathrm{N}_{2}$ を流した水蒸気電解方式では, 電気量に見合う $\mathrm{H}_{2}$ が カソードで，また $\mathrm{O}_{2}$ がアノードで発生することが確認で き, セル電圧も图 11 に示すように水蒸気電解電圧 $1.18 \mathrm{~V}$ を越えた。

〈4 2〉 膜抵抗と過電圧の整理 交流インピーダンス法 により膜の導電率 $\sigma$ を測定したところ図 13 に示すように Nguyen ら ${ }^{(5)}$ の整理式の 0.77 倍となったため, 以下の解析 


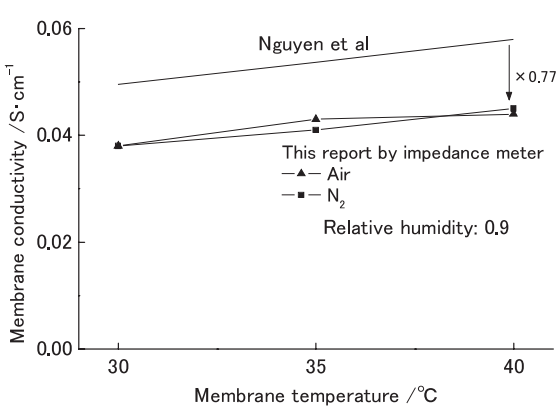

図 13 膜導電率の温度変化

Fig. 13. Change of membrane conductivity by Temperature.

では Nguyen らの 0.77 倍した値を用いた。

$\sigma=0.77 \times A_{1} \exp \left[1268\left\{1 / 303-1 /\left(273+t_{\text {cell }}\right)\right\}\right]$

ここで, $A_{1}$ は相対湿度の関数 ${ }^{(5)}$ であり，次式で与えられる。

$$
\begin{aligned}
A_{1}= & 0.00514\left(0.043+17.8 a_{j}-39.8 a_{j}^{2}+36.0 a_{j}^{3}\right) \\
& -0.00326 \ldots \ldots \ldots \ldots \ldots \ldots \ldots \ldots \ldots \ldots \ldots \ldots \ldots \ldots \ldots \ldots
\end{aligned}
$$

ここで, $a_{j}$ は流路中ガスの相対湿度で, 以下の解析では膜 抵抗は $\sigma$ を膜厚方向で積分して求めた。

過電圧 $\eta$ について, 実験的に求めた図 11 などのセル電 圧 $E_{\text {cell }}$ から $E_{\text {Nernst }}$ と膜の $\mathrm{iR}$ 損を差し引いた值を過電圧と し, 電流密度などの関数として以下のように整理した。ま ずカソードに $\mathrm{N}_{2}$ を流した時の $\eta$ は次式で近似した。

$$
\eta=0.14 \ln \{(i+0.09) / 0.0009\}+\left(K_{1}+K_{2}\right) i \cdots
$$

ここで， $i$ は電流密度 $\left[\mathrm{A} / \mathrm{cm}^{2}\right], K_{1}, K_{2}$ は光れ攵れ相対湿 度と温度の関数であり，以下のように整理した。

$$
\begin{aligned}
& K_{1}=2.99\left(a_{M E A} / 0.9\right)^{-1.67} \ldots \\
& K_{2}=-27.8\left(t_{\text {cell }} / 42\right)+29.2
\end{aligned}
$$

ここで， $a_{M E A}$ は供給ガス中の相対湿度で両極の平均値と し，アノード側の相対湿度は $27.7 \%$ 以上の範囲で実験した。 次にカソードに空気を流した時の $\eta$ は次式で近似し， $K_{1}$, $K_{2}$ は(40)，(41)式で整理した。

$$
\begin{array}{r}
\eta=0.26 \ln \{(i+0.007) / 0.0006\}+\left(K_{1}+K_{2}\right) i \\
\ldots \ldots \ldots \ldots \ldots \ldots \ldots \ldots \\
K_{1}=41.7\left(a_{w} / 0.9\right)^{2}-71.5\left(a_{w} / 0.9\right)+41.9 \ldots \\
K_{2}=45.1\left(t_{\text {cell }} / 42\right)^{2}-108.8\left(t_{\text {cell }} / 42\right)+63.7
\end{array}
$$

〈4 3〉除湿セルの解析法と解析結果流路に沿うガス 流れ方向と膜厚方向の 2 次元解析モデルを PEFC の解析モ デル ${ }^{(5)}$ と同樣に除湿セルに対して構築した。物質とエネル ギーの保存則と等価電気回路を連立させ，前章や前節で求 めたデータを使い, 以下のような仮定 ${ }^{(5)}$ の元に除湿特性を 解析した。
表 2 除湿セル出口相対湿度の実験と解析の比較

Table 2. Comparison of experimental and numerical relative humidity at outlets of dehumidifying cell.

\begin{tabular}{c|c|c|c}
\hline Type & side & Numerical & Experimental \\
\hline \multirow{2}{*}{$\begin{array}{c}\text { Water vapor electrolysis } \\
\text { outlet }\end{array}$} & Anode & 0.59 & 0.6 \\
\cline { 2 - 4 } & Cathode & 0.73 & 0.74 \\
\hline \multirow{2}{*}{$\begin{array}{c}\text { Water vapor pump } \\
\text { outlet }\end{array}$} & Anode & 0.59 & 0.59 \\
\cline { 2 - 4 } & Cathode & 0.73 & 0.74 \\
\hline
\end{tabular}

*Humidity(temperature) of inlet gas is $0.43\left(24^{\circ} \mathrm{C}\right)$ at anode, and $0.90\left(38^{\circ} \mathrm{C}\right)$ at cathode

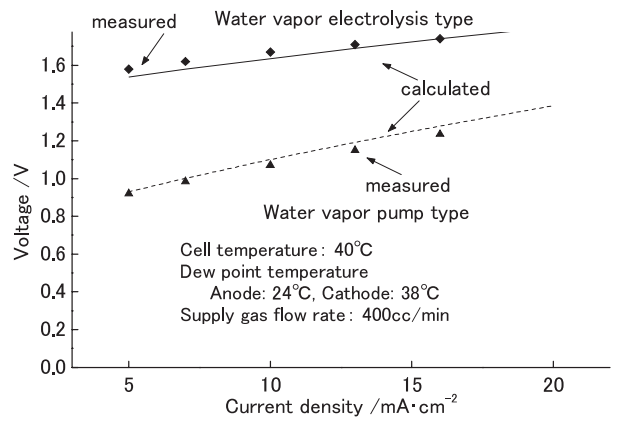

図 $14 \mathrm{i}-\mathrm{V}$ 特性の解析と実験の比較

Fig. 14. Comparison of experimental and numerical $\mathrm{i}-\mathrm{V}$ characteristics.

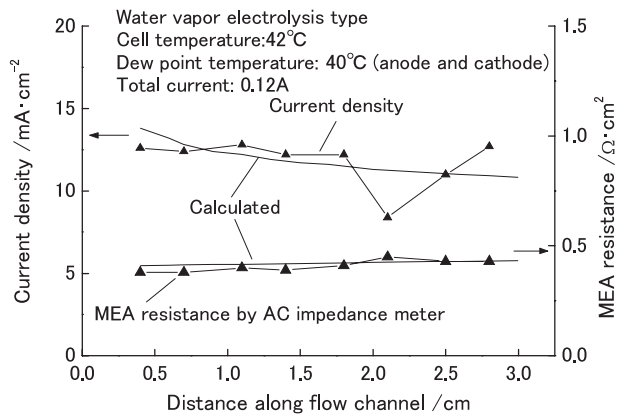

图 15 流路に沿う電流密度と $\mathrm{iR}$ 抵抗の分布 Fig. 15. Distribution of current density and MEA resistance along flow channel.

・除湿セルは並行平板型とする

・ガスは 8 本の並行ガス流路中を均等に流れる

・流路中のガス流れは plug-flow とする

・通電板には恒温水を流すため，セパレータ温度は一定 とする (MEA や拡散電極は薄いため, セル各部の温度 はセパレータ温度に近い值になる)

表 2 に除湿セル出入り口の相対湿度を解析値と実測値を 比較して示す。图 14 に実測と計算による $\mathrm{i}-\mathrm{V}$ 特性を比較し て示す。更に分割電極セル ${ }^{(6)}$ を用いて測定した流路に沿う 電流密度分布を図 15 に示す。また図 15 には交流インピー ダンス法で計った MEA の抵抗の分布も示す。実測と解析 はほぼ一致しているので, 本解析法により除湿セルの性能 を予測できることが分かる。図 15 で一部電流密度分布が 


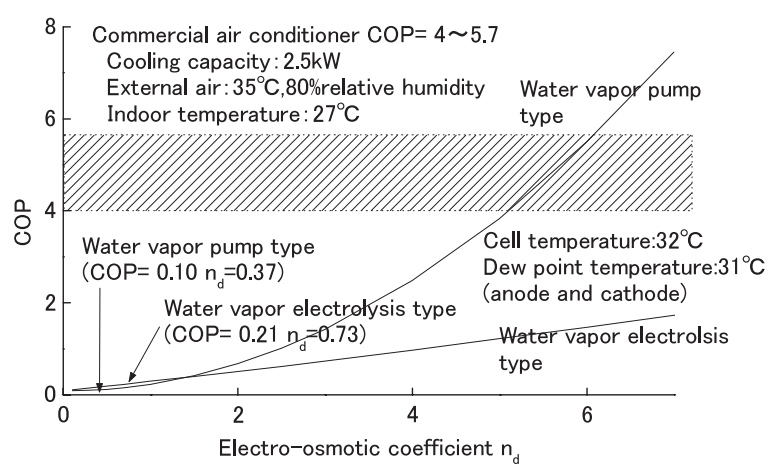

図 16 新しい空調法の $\mathrm{COP}$ の $n_{d}$ に対する変化 とフロン空調法との比較

Fig. 16. Change of COP for novel air conditioner by $n_{d}$ and its comparison with commercial air conditioner.

ばらついているのは, 分割電極と拡散電極の接触が一樣で なかったためと考えられる。

〈4 4〉 除湿セルの空調への応用 以上述べた除湿セル と，水の蒸発潜熱を利用した冷風扇を組み合わせることに

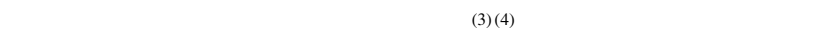
て, 水蒸気ポンプ方式あるいは水蒸気水電解方式による除 湿セルを用いた空調法の COP を試算し，フロンによる市 販空調機の性能と比較してみた。除湿セルと外気の温度は $32^{\circ} \mathrm{C}$, 外気露点温度は $31^{\circ} \mathrm{C}$ とすると, 電解動力のみを考 慮して水電解方式では $n_{d}=0.73$ で $\mathrm{COP}=0.21$ となり，水 蒸気ポンプ方式では $n_{d}=0.37$ で $\mathrm{COP}=0.10$ となった。空 気をカソードに供給すると電圧は下がり，除湿セルの電解 動力も下がるが，カソードで水が生成し，逆拡散により正 味除湿量が減るため, COP は水蒸気電解方式より低くなっ た。理想的な (5) 式に逆拡散や過電圧損失を加え, ブロア などの補機動力を無視して, 水蒸気電解方式と水蒸気ポン プ方式の本空調法の COP は (42) 式でほぼ近似できる ${ }^{(4)}$ 。

$$
C O P=\frac{T \Delta S+\left\{2\left(n_{d}-D_{a l l} \Delta C / d_{M E A+D I F} \cdot F / I\right)+1\right\} L}{\Delta G+2 F \eta}
$$

ここで, $F$ はファラデー定数,$I$ はセル電流 $[\mathrm{A}], D_{\text {all }}$ は除湿 セル全体での拡散係数 $\left[\mathrm{cm}^{2} / \mathrm{s}\right], \Delta C$ は水蒸気濃度差 $\left[\mathrm{g} / \mathrm{cm}^{3}\right]$, $d_{M E A+D I F}$ は MEA と拡散電極の合計厚さ $[\mathrm{cm}]$ である。(42) 式で, 水蒸気ポンプ方式ではカソードで $\mathrm{H}_{2} \mathrm{O}$ が生成するた め, 水蒸気電解に必要な $T \Delta S$ と $\Delta G$ は消える。本実験で 測定した $n_{d}$ の値では COP は低かったが，もし大きな $n_{d}$ を 持つ MEA があれば，逆拡散量より電気浸透による汲上げ 量が大きくなり，COP も図 16 のように増大する。現状の 性能では一部で使われ始めている乾燥容器や制御箱 ${ }^{(1)(2)}$ どの特殊用途に限定されようが，もし $n_{d}=5$ の MEA か開 発されれば，市販のフロン空調機と同程度の性能を持つこ とになる。現状では $n_{d}$ に対する理解が充分でなく， $n_{d}$ を 制御できる製法も開発されていないようであるが，水電解 て使われる MEA は $n_{d}=4.8^{(6)}$ が得られているので, 今後 大きな $n_{d}$ を持つ MEA の開発が期待される。

\section{5. むすび}

除湿セルに使われる固体高分子膜の水蒸気に対する透過 係数や電気浸透係数, 拡散電極の拡散係数, 流路の物質伝 達係数を実測し，得られたデータを用いて除湿セルの除湿 特性を解析し, 水蒸気電解方式や水蒸気ポンプ方式の除湿 実験結果をほほ説明することが出来た。この除湿セルを水 の蒸発潜熱を利用する冷風扇と組み合わせた新しい空調法 を提案し ,この空調法のCOP を試算し,市販のフロン空調 機と比較した。本空調法の COP は水蒸気電解方式で 0.21 , 水蒸気ポンプ方式 0.10 とかなり低く, 乾燥容器や制御箱の ような特殊用途であれは現状でも使われようが，市販空調 機と同等の性能を持つには, 約 5 の電気浸透係数が必要で あることが分かった。なお，本研究の一部は (独) 産業技 術総合研究所の西村靖雄氏, 藤原直子氏と旭硝子の吉武優 氏に多大なこ助力を，また平成 12,13 年度に RITE 優秀研 究企画の援助を受けたことを付記し，ここに感謝の意を捧 げる。

(平成 16 年 2 月 18 日受付, 平成 16 年 5 月 21 日再受付)

\section{文献}

(1) E. Kurosaki, K. Emoto, S. Yamauchi, H. Nakatani, T. Mochizuki, E. Tsuchie, and T. Hanada: "Reliability of Electrolytic Dehumidifier Using SPE Membrane", The Fourteenth Annual Conference of Power \& Energy Society. IEE Japan, Vol.B, p.87 (1998) (in Japanese)

黑崎恵美 · 江本邦夫 ·山内四郎 - 中谷 元 - 望月哲夫 · 土江 瑛 · 花田武明 : 「電解式 SPE 除湿器の信頼性評価」, 平成 10 年電力エネ ルギー部門大会, Vol.B, p.87 (1998)

(2) S. Yamauchi, S. Sakuma, H. Nakatani, and K. Mitsuda: "Mass Transfer Equations of Electrolytic Water Removal Device Using Solid Polymer Membrane", T. IEE Japan, Vol.120-A, No.5, p.607 (2000-5) (in Japanese) 山内四郎・佐久間秀一・中谷 元・光田憲朗 : 「固体高分子電解質膜 を用いた電解式除湿器の水移動特性」, 電学論 A, 120, 5, p.607 (2000-5)

( 3 ) R. Notsu, T. Murakami, T. Aoki, and K. Onda: "Test of Novel Air Conditioner by Solid-Polymer Dehumidifying Cell", 2000 National Convention Record IEE Japan, p.3373 (2000) (in Japanese)

野津良平・村上敏夫・青木哲也・恩田和夫 : 「固体高分子除湿セルを 用いた新しい空調法の試験」, 平 12 電気学会全大, p.3373 (2000)

(4) K. Onda, K. Ito, T. Kyakuno, and K. Hattori: "Study on Novel Air Conditioner with Endothermic Water Vaporization and Dehumidification by Cation Exchange Polymer Film", RITE Excellent Research Plan Research Report Meeting in the Heisei 14 Fiscal Year, p.95 (2003) (in Japanese) 恩田和夫・伊藤衡平・客野貴広・服部紀公士 : 「水の蒸発吸熱と力チ オン交換膜による除湿を併用する新しい空調法の研究」, RITE 優秀 研究企画平成 14 年度研究報告会, p.85 (2002)

( 5 ) T.V. Nguen and R.E. White: "A Water and Heat Management Model for Proton-Exchange-Membrane Fuel Cells", J. Electrochem. Soc., Vol.140, No.8, p.2178 (1993)

( 6 ) K. Onda, T. Murakami, T. Hikosaka, M. kobayashi, R. Notsu, and K. Ito: "Performance Analysis of Polymer-Electrolyte Water Electrolysis Cell at a Small-unit Cell and Performance Prediction of Large Stacked Cell", J. Electrochem. Soc., Vol.148, No.8, p.A1069 (2002)

( 7 ) W.M. Rohsenow and H.Y. Choi: Heat, Mass and Momentum Transfer, p.405, Prentice-Hall, Inc. (1963)

( 8 ) H. Ymada and Y. Morimoto: "Electro-osmotic Drag and Diffusion Coefficient of Water in Polymer Electrolyte Membrane", 3N19, J. Electrochem. Soc., 70th Anniversary Convention of Foundation, p.316 (2003) (in Japanese)

山田晴彦・森本 友 : 「固体高分子電解質膜の電気浸透係数と拡散 係数」, 3N19, 電気化学会創立 70 周年記念大会, p.316 (2003)

（9）安田和明: 固体高分子型燃料電池の開発と応用, p.41, エヌ・ティー・ エス (2000) 
客 野 貴 広 (学生員) 1979 年 11 月 7 日生。2002 年 3 月豊

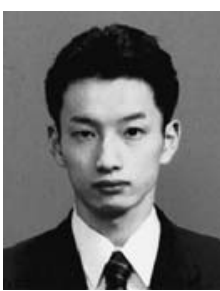
橋技術科学大学工学部電気・電子工学課程卒業。 同年 4 月同大学大学院工学研究科電気・電子工学 専攻修士課程に入学, 現在に至る。主として高圧 水電解に関する研究に従事。

服 部 紀公士

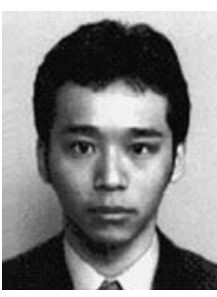

(学生員) 1979 年 2 月 15 日生。 2003 年 3 月豊 橋技術科学大学工学部電気・電子工学課程卒業, 同年 4 月同大学大学院工学研究科電気・電子工学 専攻修士課程に入学, 現在に至る。主として, 水 電解に関する研究に従事。

池 田 孝 伸

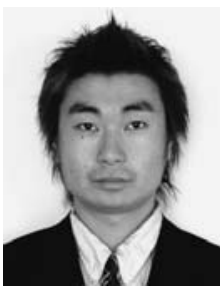

(学生員) 1981 年 5 月 29 日生。 2002 年 4 月豊 橋技術科学大学工学部電気電子工学課程卒業, 同 年 4 月同大学大学院工学研究科電気・電子工学専 攻修士課程に入学, 現在に至る。主として, 水電 解に関する研究に従事。

荒 木 拓人 (正員) 1975 年 5 月 2 日生。 2003 年 3 月京都大

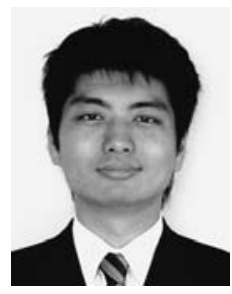
学大学院工学研究科博士課程修了。2004 年 1 月 豊橋技術科学大学電気電子工学専攻助手。主とし て, 燃料電池, 水電解, 二次電池, 放電脱硝の研 究に従事。電気化学会, 機械学会, 伝熱学会会員。 工学博士。

恩田 和夫

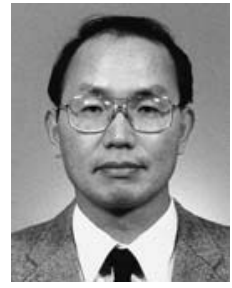

(正員) 1941 年 6 月 20 日生。1966 年 3 月東京 工業大学大学院理工学研究科修士課程修了。同年 10 月電子技術総合研究所入所。1995 年 9 月豊橋 技術科学大学教授 (電気電子工学系)。主として, 燃料電池, 水電解, 二次電池, 放電脱硝の研究に 従事。電気化学会, 応用物理学会, 日本機械学会, エネルギー・資源学会会員。工学博士。 